DOI: 10.1515/LPTS-2015-0007

PHYSICAL AND TECHNICAL ENERGY PROBLEMS

\title{
EFFECTS OF USING CHANNELLING DEVICES TO INCREASE EFFICIENCY OF HYDROKINETIC DEVICES
}

\author{
A. Kalnacs ${ }^{1}$, J. Kalnacs ${ }^{2}$, A. Mutule², V. Entins ${ }^{3}$ \\ ${ }^{1}$ Riga Technical University, \\ 1 Kalı̧ Su Str., LV-1658, Riga, LATVIA \\ E-mail: ansis.k@gmail.com \\ ${ }^{2}$ Institute of Physical Energetics \\ 21 Aizkraukles Str., LV-1006, Riga, LATVIA \\ ${ }^{3}$ LLC „Environment, Bioenergetics and Biotechnology Competence Centre” \\ 21 Aizkraukles Str., LV-1006, Riga, LATVIA \\ In the rivers of Latvia and of many other countries the flow velocity \\ in the places that are most suitable for installation of hydrokinetic devices is \\ 0.4 to $0.9 \mathrm{~m} / \mathrm{s}$. In a stream or a river the hydrokinetic devices can reach full \\ efficiency starting from about twice higher flow velocities. It is advisable to \\ at least double this velocity thus increasing the efficiency and power output \\ of the hydrokinetic devices installed in such places. Since Latvia has abun- \\ dance of slow rivers and almost none are fast, research in this field is of high \\ importance. Diversified technical methods are known that allow increasing \\ substantially the efficiency of hydrokinetic devices. These methods include \\ the use of diffusers, concentrators, different types of other channelling devices \\ and means of flow control. Desirable effects are achieved through changing \\ the cross-section and/or direction of a flow, its pressure, minimizing the tur- \\ bulence, etc. This work substantiates the use of such devices for increasing \\ the efficiency of hydrokinetic devices. A method is proposed for evaluation of \\ the effects on power output gained owing to the use of channelling devices. \\ Results show that the efficiency of hydrokinetic devices can be increased by \\ at least $110 \%$.
}

Keywords: Hydroelectric power generation, microhydro power, flow velocity, hydrokinetic device, channelling device.

\section{INTRODUCTION}

Hydrokinetic technologies receive much attention and are developing rapidly in the last decade [1-4]. They enable extraction of energy from waves and free flows 
of water in the seas, oceans, and rivers. Depending on the source of energy, there could be wave, tidal and free flow hydrokinetic technologies. Most concentrated energy is in waves and tidal streams. This explains why more attention and research are devoted to the wave and tidal hydrokinetic technologies. The least concentrated energy is in river streams. At the same time, the river flow technologies have their own advantages, the most important being as follows.

- It is much easier to extract energy from free flow than from waves.

- Many consumers of electricity live (or work) in close proximity to the rivers (as opposed to the seas and oceans with tall waves, high tides and strong flows).

- Simpler and cheaper connection to the grid and maintenance as compared with the power plants operating on wave, tidal and sea free flows and are therefore sited at a considerable distance from the coast.

- The river environment is much more friendly to the technical power plant equipment than that of see or ocean, which makes the river-related devices less complicated and less expensive.

- The direction and velocity of tidal (and in many cases also sea) flows can vary, whereas river flows are unidirectional and usually do not change much in velocity. This also makes the river technology less complicated.

In the case of Latvia, with no tidal energy available, the river free flow devices can be utilized for supplying power of up to $1 \mathrm{MW}$ to stand-alone objects or object groups. The wave power plants in Latvia can be used to generate larger amounts of power and to supply it to the grid.

Still, the potential of the river free flow hydrokinetic energy is high enough.

Taking into account the kilometrage of rivers, the hydrokinetic (free flow) devices may become one of the main local renewable energy sources that do not produce emissions.

In Latvia, the density of rivers' network is $0.6 \mathrm{~km}$ per square kilometre [5]. Assuming that 10 square metres of a river (average depth $1 \mathrm{~m}$, average width $10 \mathrm{~m}$ ) are used for electricity production, a very rough estimate (based on the assumptions and the data from the work described in Ch. 3) is $100 \mathrm{MWh}$ of electricity per year that can be derived in Latvia from a square kilometre. As related to the Latvian territory of $64589 \mathrm{~km}^{2}$, this gives a total of $6.46 \mathrm{TWh}$. It should be stressed that we are dealing with a renewable and sustainable energy source. This energy is produced without emissions while keeping rivers available for other uses, with negative impact on the environment close to zero.

Given the indications of a considerable potential of hydrokinetic energy from rivers and a comparatively lower concentration of this energy, two major questions deserving research are the following: how to increase the concentration of this energy, and how to evaluate its potential and the effect from increasing its concentration. 


\section{CHANNELING DEVICES AND THEIR EVALUATION}

As mentioned above, the only major disadvantage of the river free flow hydrokinetic technologies compared with others of the type is the lowest concentration of energy. The power of a single hydrokinetic device (HKD) and the power that can be obtained from one cross-section of the river with this type of devices are calculated by the same formula:

$$
N=k \cdot v^{3} S \cdot \rho,
$$

where $k$ is an empirical coefficient depending on the HKD;

$v$ is the flow velocity before (upstream) the HKD or the cross-section $(\mathrm{m} / \mathrm{s})$;

$S$ is the cross-sectional area of the flow $\left(\mathrm{m}^{2}\right)$;

$\rho$ is the flow (water) density, $\mathrm{kg} / \mathrm{m}^{3}$;

$m=(v \cdot S \cdot \rho) \quad$ is the mass of water per second flowing through the HKD or the cross-section.

Flow velocity affects the most the power output of hydrokinetic free flow power plants. The concentration of energy in the free flow is increasing with the flow velocity and faster by a factor of $10^{3}$ than that. The output of a power plant is affected not only directly (as follows from Eq. (1)), but also indirectly, through the changes in the efficiency coefficient (included in constant $k$ from Eq. (1)).

The flow velocity usually transforms into the rotational speed of the turbine, with the generator efficiency increasing with the rotational speed. This shows a way for improving the efficiency of free flow hydrokinetic power plants. Using Bernoulli's law, the possibilities to concentrate the kinetic energy and to improve the efficiency of a relevant device are exploited using different type channelling devices [6-10]. While increasing the flow velocity, channelling devices also reduce the available area covered by the active elements (such as propellers, blades, and the like) of an HKD. This area is equal to that covered by the channeling device itself, and thus cannot be covered by these active elements. The result is a reduced $S$ value (see Eq. (1)), which causes a linear decrease in the output power of the device. Since at a velocity increase the power is cubed, the gains in power are higher than the losses due to reduced area $S$.

Channelling devices are simpler, require less maintenance than HKDs, and do not have moving parts. Therefore, the HKD equipped with a channelling device is usually less costly to produce and maintain than that without such a device which would cover the same area.

The use of channelling devices can also increase costs in some aspects; however, these are far outweighed by the gains to be achieved. Since the channelling devices are clear obstacles for the flow, they are subject to significant drag forces $[10,11]$. Thus, the major aspect of cost increase that should be considered is mooring of the channelling devices. This aspect is also important when choosing dimensions and shape of the channeling device as well as when developing new ones. These two 
words (channelling device) seem to make the most universal term from the reviewed in literature for all devices of this nature. Similar terms are concentrator, diffuser, and duct. Diffuser refers to a channelling device having an outlet (or nozzle) after (downstream) the HKD which has larger or the same cross-section area than the inlet covered by the active HKD elements. The term duct can also be attributed to the channelling devices. Therefore, the term channelling device is here chosen as relevant and most appropriate from the reviewed ones to refer to all devices of the type (see Fig. 1 for the examples of channelling device).

A

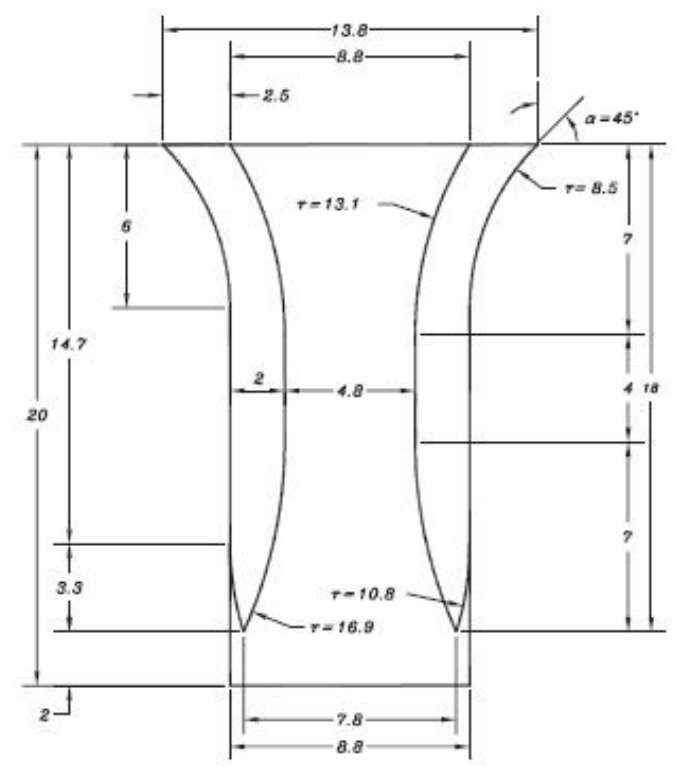

B

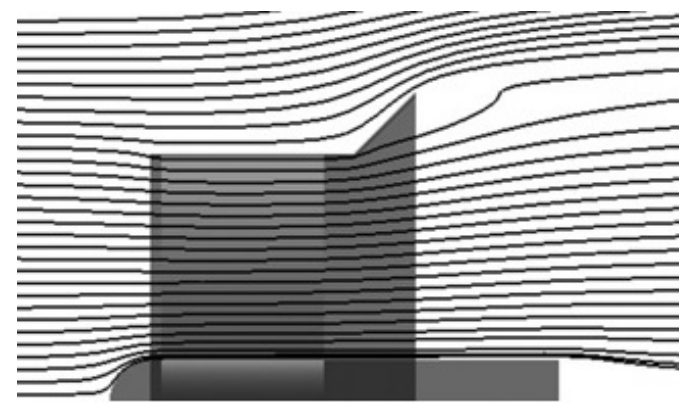

Fig. 1. Examples of channelling device (A taken from [12]; B taken from [10]))

As shown in works $[13,14]$, the channelling devices can be highly diversified, providing a significant velocity increase for the flow that operates an HKD. Consequently, channelling devices can be used to increase considerably the energy concentration in a free flow. As the river free flow possesses the least energy concentration, the relevant technology can gain the most from channelling devices as compared with other hydrokinetic technologies.

Channelling devices also provide opportunities to extract power from a free flow beyond the Betz limit $[10,15,16]$. According to this limit, for the maximum 
extraction from a free flow $60 \%$ of its kinetic energy can be utilised, but in this case it is assumed that the entire inlet area of the flow is swept by the active parts of turbine, with the presence of a channelling device ignored.

The efficiency of channelling devices in raising the concentration of the free flow kinetic energy increases when this concentration becomes lower [12]. This provides more opportunities for using free flow HKDs in plain regions with many calm rivers, such as in Latvia, all Baltic countries and many other parts of the world. The results of flow velocity measurements in the Latvian rivers show that in most of the places suited best for HKD operation the flow velocity is between 0.4 and $0.9 \mathrm{~m} / \mathrm{s}$. For efficient operation of these devices, it is advisable to place them into at least two- to three-times faster flows. Possible designs and operation of channeling devices for rivers with flow velocities around and below $1 \mathrm{~m} / \mathrm{s}$ are least studied while having the highest potential in the field under consideration.

River HKDs represent rather a new technology and most of these devices - especially the most promising of them - are only in their initial stages of development. Thus, their potential is usually evaluated only theoretically, or under very specific but not often met real circumstances.

The choice among the variety of rivers, hydrokinetic devices, and channelling devices is wide enough. Thus, it is important to evaluate the potential of a river in general and, in particular, of specific HKD and channelling devices. This would be helpful when choosing the best sites for deployment of hydrokinetic devices as well as the best HKDs and channelling devices for a particular segment of the river.

Therefore, a method is required that would allow both the evaluation of the potential river energy and that of the results obtained using a specific hydrokinetic technology.

\section{EVALUATION METHOD}

The method for evaluation of the river energy potential in view of prospective siting of power plants based on hydrokinetic devices was developed to assess particular spans of river Daugava in Latvia [17]. This method can also be used for evaluation of any river or its span where it is possible to move by boat or any similar floating device and keep this floating device motionless against the banks of the river. The method covers also the validations of the obtained flow velocity, bed depth and other measurement data against the statistical data on the flow rate (for full description see [18]).

The method consists of the following consecutive steps:

1. Measurements of the flow velocity and the river bed depth in several river cross-sections.

2. Validation of the obtained measurement data. The data on the flow rate calculated at the time of measurements are to be compared with the statistical flow rate averages. For the Latvian rivers the required statistical data can be taken from internet [19]. 
3. To reduce unnecessary workload, the river segments where the bed depth, the flow velocity or other obtained critical characteristics are not satisfactory are to be excluded from further evaluation and analysis.

4. The explored spans of the river should be rearranged into segments according to the flow velocity and other critical characteristics. The spans that have been explored and are retained for further analysis should be arranged into continuous segments with approximately equal critical characteristics throughout the entire segment. It could be necessary to assess several such characteristics at evaluation of a particular technology. For example, the average bed depth and/or the cross-section width in addition to the flow velocity are to be considered. Thus, the segments will be determined where a definite number of relevant devices can be set up in a single cross-section (next to and/or above/below each other).

5. For all segments defined in step 4 the potential for production of electrical power should be calculated based on formula (1). To calculate this potential, the following parameters are to be defined:

a. the cross-sectional area of the river that is used by HKDs,

b. the efficiency of the HKDs,

c. the efficiency of the electricity generator,

d. the distance between the HKDs in the direction of river flow,

e. the number of idle standing days in a year.

f. the area ratio of the channeling device (i.e. outlet area/inlet area of the channeling device) [10]: this parameter takes into account the area that the channelling device occupies and thus reduces the $S$ value in Eq. (1).

g. the efficiency of HKD if used together with a channelling device: this parameter takes into account gains in $v$ and $N$ (see (1))

To enable evaluating the use of a channelling device, the previous methodo$\operatorname{logy}[17,18]$ is updated with two parameters ( $\mathrm{f}$ and $\mathrm{g}$ ) in addition to the (a-e) ones.

\section{RESULTS}

The table containing final results for the evaluation is also updated with several columns to allow comparison among different segments of a river, different HKDs and their performance with and without the channelling devices (see columns $10-15$ in Table 1)

The flow velocity and bed depth data for Table 1 are taken from [17], where all the calculations and analysis of the data not concerning the channelling devices can be found. The data on channelling device A are taken from [12], and on channelling device $\mathrm{B}-$ from [10] regarding the channelling device E1A6 profile. The channelling devices are illustrated in Fig. 1 (Ch. 2).

The data in Table 1 show that the use of channelling device A can increase the electricity production by $47 \%$, while channelling device B enables achieving increase by $110 \%$. The performance data of channelling device A have been obtained from empirical experiments. For channelling device A the best practically proved 


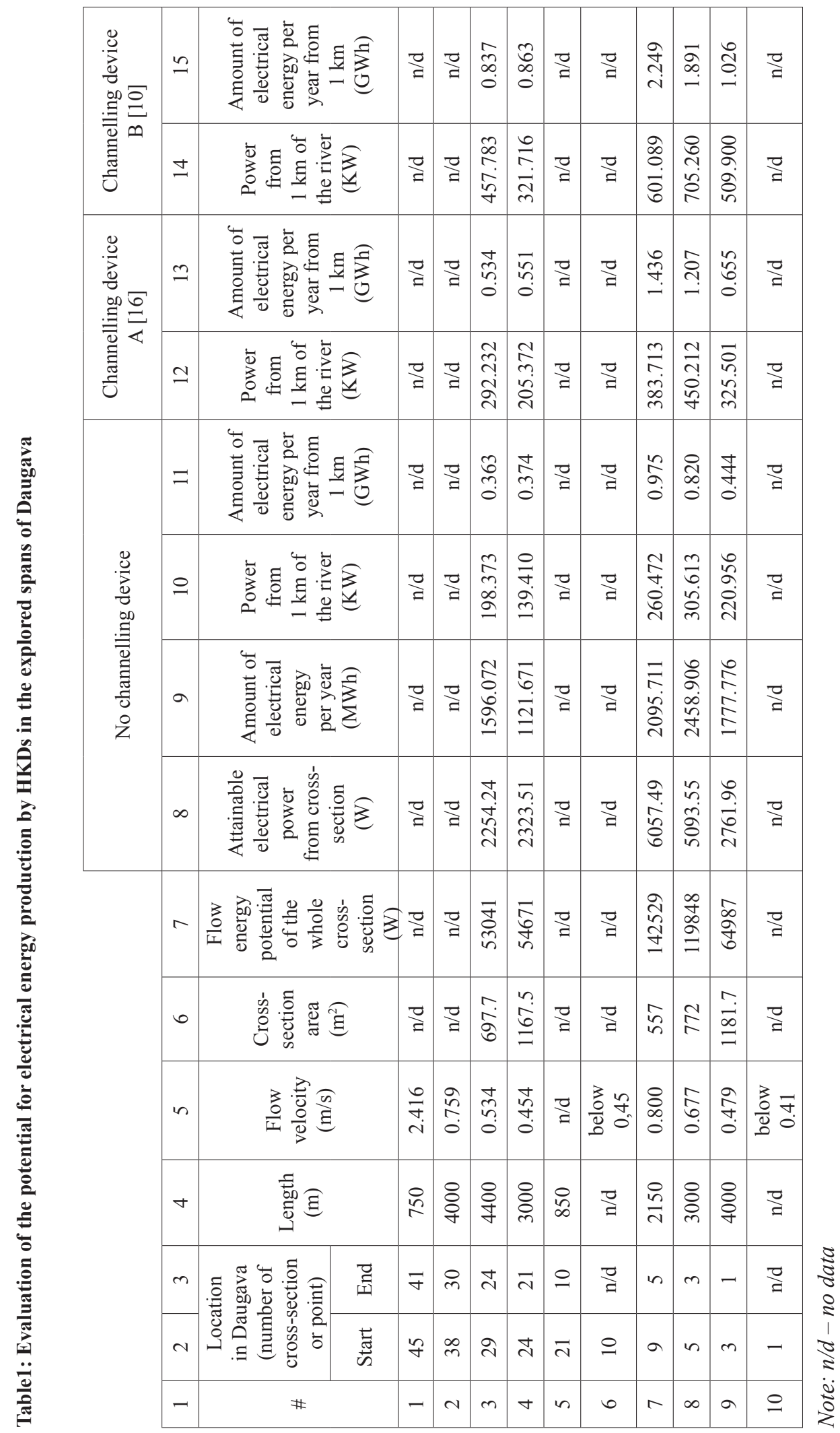


results have been found by the internet search performed for this work. Channelling device $\mathrm{B}$ has more than twice better performance, but as of now it is only a theoretical device and its performance is also theoretical.

The results of calculations show that channelling devices can increase the electricity production substantially, thus raising the HKD efficiency. These devices are least studied regarding the use with flow velocities of $\sim 1 \mathrm{~m} / \mathrm{s}$ and below, but their efficiency is higher just at these lower flow velocities. This provides opportunities for using HKD with channelling devices particularly in slower rivers. Provided that there is a theoretical possibility to improve the efficiency of channelling devices to at least $110 \%$ energy production, it is even more prospective field of research for the countries with many slow rivers.

The theoretical data regarding the performance of channelling devices at the flow velocities $<1 \mathrm{~m} / \mathrm{s}$ should be verified in experiments where the optimal dimensions of the channelling device are also chosen for each particular HKD.

\section{CONCLUSIONS}

Based on the results of work, the following conclusions regarding the use of channelling devices in combination with hydrokinetic devices can be drawn:

- Calculations show that the use of channelling devices can give 50\%-110\% increase in the HKD electricity production.

- Channelling devices is a promising solution for improving the HKD efficiency - especially that of river free flow devices as well as of others of the type.

- Effects of using a channelling device can be evaluated by the method proposed in this work.

- Extensive research should be done to develop channeling devices for the rivers with flow velocities around and below $1 \mathrm{~m} / \mathrm{s}$ as they are least studied so far while being highly promising for improvement of HKD efficiency.

- Reduction in the drag due to channelling devices and effective mooring solutions for withstanding the drag forces will be among the top priorities in further research and development of these devices.

\section{ACKNOWLEDGEMENT}

This work has received a financial support of the European Regional Development Fund according to the agreement between LLC „Environment, Bioenergetics and Biotechnology Competence Centre" and "Investment and Development Agency of Latvia" as of April 11, 2011 regarding implementation of the project \# L-KC-11 -0005. Complete research results are available at www.vbbkc.lv 


\section{REFERENCES}

1. Khan, M.J., Bhuyan, G., Iqbal, M.T., \& Quaicoe, J.E. (2009). Hydrokinetic energy conversion systems and assessment of horizontal and vertical axis turbines for river and tidal applications: A technology status review. Applied Energy, 86 (10), 1823-1835.

2. Lago, L.I., Ponta, F.L., \& Chen, L. (Dec. 2010). Advances and trends in hydrokinetic turbine systems. Energy for Sustainable Development, 14(4), 287-296.

3. Sųrnes K.; Small-scale Water Current Turbines for River Applications; January 2010; ZERO - Zero Emission Resource Organisation; www.zero.no

4. Khan, M.J., Iqbal, M.T., \& Quaicoe, J.E. (2008). River current energy conversion systems: Progress, prospects and challenges. Renewable and Sustainable Energy Reviews 12(8), 2177-2193.

5. Rudovic, A. (1996). Latvijas fiziskā geogräfija. Zvaigzne ABC; 1996.

6. Mukrimin, S.G. (2011). Evaluation and measures to increase performance coefficient of hydrokinetic turbines. Renewable and Sustainable Energy Reviews, 15, 3669-3675.

7. Wang Sh., Xu Ch., Yuan P., \& Wang Y.; (2011) Hydrodynamic optimization of channelling device for hydro turbine based on lattice Boltzmann method. Computers and Mathematics with Applications, 61, 3722-3729.

8. Malipeddi, A.R., \& Chatterjee, D. (2012); Influence of duct geometry on the performance of Darrieus hydroturbine. Renewable Energy, 43, 292-300.

9. Shiomi, N., Setoguchi, T., Kinoue, Y., Kaneko, K., \& Ohya, Y. (2003). Development of Two-Way Diffuser for Tidal Energy Conversion System. Proceedings of the $13^{\text {th }}$ International Offshore and Polar Engineering Conference. Honolulu (Hawaii USA), May 25-30.

10. Gaden, D.L.F., \& Bibeau, E.L. (2010). A numerical investigation into the effect of diffusers on the performance of hydrokinetic turbines using a validated momentum source turbine model. Renewable Energy, 35, 1152-1158.

11. Setoguchi, T., Shiomo, N., \& Kaneko, K. (2004); Development of two-way diffuser for fluid energy conversion system. Renewable Energy, 29, 1757-1771 (technical note).

12. Ponta, F., \& Jacovkis, P. (2008). Marine-current power generation by diffuser-augmented floating hydro-turbines. Renewable Energy, 33, 665-673.

13. Lawn, CJ. (2003). Optimization of the power output from ducted turbines. Proceedings of the Institution of Mechanical Engineers, Part A (Journal of Power and Energy, 217, 107-117).

14. Phillips, D.G., Nash, T.A., \& Oakey, A., Flay, R.G.J., \& Richards, P.J. (1999). Computational fluid dynamic and wind tunnel modelling of a diffuser augmented wind turbine. Wind Engineering, 23, 17-13.

15. Betz, A. (1926). Wind-Energie und ihre Ausnutzung durch Windmuehlen. GoØttingen: Bandenhoeck \& Ruprect.

16. Jamieson, P. (2008). Generalized limits for energy extraction in a linear constant velocity flow field. Wind Energy, 11, 445-457.

17. Kalnacs, J., Kalnacs, A., Mutule, A., \& Pērsis, U. (2013). Potential of the lower Daugava for siting hydrokinetic turbines. Latv. J. Phys. Tech. Sci., 50, 3-14.

18. Kalnacs, A., Kalnacs, J., Mutule, A., \& Pērsis, U. (2008). Methods for estimation of the riverflow potential for hydrokinetic power generation. Latv. J. Phys. Tech. Sci.,51, 26-36.

19. State Limited Liability Company "Latvian Environment, Geology and Meteorology Centre": Link to the internet $<w w w$. meteo.lv $>$ 


\title{
VADOTN̦U IETEKME, TĀS LIETOJOT HIDROKINĒTISKO UPJU IEKĀRTU EFEKTIVITĀTES PALIELINĀŠANAI
}

\author{
A. Kalnačs, J. Kalnačs, A. Mutule, V. Entins
}

Kopsavilkums

Kā rāda pētījumi, Latvijā upju vietās, kuras ir piemērotas hidrokinētisko HES ierīkošanai, straumes ātrums pārsvarā ir robežās 0,4 līdz $0,9 \mathrm{~m} / \mathrm{s}$. Būtu izdevīgi vismaz dubultot šo ātrumu, līdz ar to būtiski palielinot šādās vietās izvietojamo iekārtu efektivitāti un jaudu. Sakarā ar to, ka Latvijā ir daudz tieši lēni plūstošu upju, minēto tēmu izpēte un iekārtu izmantošana Latvijai ir sevišķi aktuāla.

Ir zināmi dažādi tehniskie paņēmieni, kas dod iespējas būtiski palielināt hidrokinētisko iekārtu efektivitāti. Šādas iespējas dod koncentratori, difuzori, dažādi plūsmas virzîtāji un citi speciāli plūsmas vadības pañēmieni. Šīs ierīces maina straumes šḳērsgriezumu un/vai virzienu, maina spiedienu straumē, minimizē turbulenci. Šajā darbā apskatītas iespējas palielināt hidrokinētisko iekārtu efektivitāti, lietojot šādas ierīces, ka arī metode, kā novērtēt sagaidāmo ieguvumu no minēto ierīču lietošanas. Darbā ir aprēķināts, ka vadotņu izmantošana var palielināt hidrokinētisko iekārtu efektivitāti par vismaz 110\%, neradot ne lielas izmaksas, nedz arī būtisku negatīvu ietekmi.

03.03.2015. 